\title{
INITIATIVES FOR TRANSPARENCY-BUILDING IN TURKEY: INTERNATIONAL, REGIONAL AND DOMESTIC FACTORS ${ }^{1}$
}

\author{
Nilufer NARLI
}

\section{Introduction: Concepts and Effort in Southeast Europe}

In democratic states, governments are accountable to the public for their actions and spending. It is the executive's obligation to reveal, explain and justify actions (policy accountability) and expenditures (financial accountability); and it is a legislative duty to review, debate and approve what the government does or proposes in these areas. Transparency is a key element in fulfilment of the accountability obligation and indispensable for 'democratic control' of public affairs. Transparency building, with the aim of improving public information about governmental spending in various fields, including defence, is a recent concern for Southeast Europe. ${ }^{2}$ However, since the year 2000 it has received considerable attention in the region. ${ }^{3}$

Examination of transparency-building in defence budgeting calls for a holistic approach and analysis at three levels: international, regional, and national (or domestic) transparency, elaborating on David Greenwood's differentiation. ${ }^{4}$ At the domestic level, it is a matter of providing informative facts and figures to elected representatives, to the media and academia, and to society-at-large. As noted above, there is an obligation on the part of the government to provide such information because in democratic societies transparency is "the guarantor of accountability." 5 However, there is also a complex relationship between citizens, their elected representatives, executive ministries, General Staffs and security forces in general. At the regional level, transparency is sharing fairly detailed facts and figures about defence programmes and provision among neighbours. It is important for regional stability and good-neighbourly relations because it is a confidence- and securitybuilding practice. At the international level, it is about sharing information with neighbours and other countries and with international agencies. ${ }^{6}$ It is important for 
confidence- and security-building at this level also. The Organisation for Security and Co-operation (OSCE) in Europe co-ordinates and facilitates exchange of information on military budgeting in and around Europe, based on the provisions of the so-called Vienna Document 1999. ${ }^{7}$ These arrangements promote both regional and international transparency.

Initiatives for transparency-building come from various sources: citizens, political elites, the military, international organisations. Typically success requires popular pressure and political will on the part of a government. In infant democracies and 'transition' states, where the democratic culture is immature, the societal urge for transparency may be insistent.

Turkey is good case in point. Accordingly, this paper analyses how and to what extent a number of sociological and international variables have influenced Turkish citizens' initiatives for transparency-building in military resource planning and budgeting. Among the sociological factors are the unique role of the army in political decisionmaking and society's perception of the military and its political function. In addition, the analysis focuses on the interaction among international, regional and domestic factors in shaping initiatives.

What are the relevant factors at these three levels? At the international level they are shifts in the balance of power (e.g., the demise of the Soviet Union and the ending of the Cold War), international treaties concerning armaments (e.g., the CFE treaty) and international agreements on various security matters (e.g., the Vienna Document 1999), new global threats (e.g., terrorism, especially since the attacks in the US on 11 September 2001) and actual or potential wars (e.g., the recent hostilities in Iraq). The magnitude of the perceived or real threat brought about by such developments is clearly influential. At the regional level, inter-state armed conflicts, border disputes and tension between nations over limited natural resources (e.g. water) are likely to affect popular pressure for transparency of defence planning, programming and budgeting. At the domestic level, economic, political and socio-political factors enter the reckoning. The former include experience of fiscal crisis and chronic poverty. The latter comprise perceived and real threats to national security; the activities of separatist or extremist movements; the political culture defining the position of the military vis-à-vis society and the political elite, and the nature of civil-military relations generally; and the impact of reforms that change legal and political frameworks. 


\section{Civil-Military Relations and Planning Defence Resources and Budgeting in Turkey}

\section{Civil-Military Relations}

In Turkey, despite their formal separation, military and civilian authorities have forged a partnership based on an (imperfect) concordance among the military, political elites, and the citizenry. This ruling style is the product of the country's specific cultural, social, and institutional context, featuring a stratified society and political culture as well as historic conflicts with neighbouring states and a constant fear of losing territorial integrity (regarded as synonymous with national integrity).

Moreover, three major convictions in the political culture, which are internalised in the course of primary and secondary socialisation, enhance the tendency to deny the separation of civilian and military spheres and sustain the military's influence in civilian political decision-making. They back the constitutional provisions that enable the military to intervene in the legislative process. $^{8}$ These convictions are: Turkey has been known as a military-nation throughout history ${ }^{9}$ every male Turk is a born soldier; and the military not only protects Turkey against internal and external enemies, but also ensures secularism and democracy in the country. The foregoing significantly influence the military's role in the nation.

Originally Ataturk's victorious army stood aside from politics, in the name of creating a democratic republic. Nevertheless, over the years the military was gradually to become a stronger presence, with broad public support; and through the 1980s and 1990s certainly the military continued to a have a strong influence in Turkish politics. Although the international environment favoured the establishment of democratic systems and (then) Prime Minister Ozal tried to curtail the political power of the officer corps, the military was able to sustain its political influence due the separatist Kurdish insurgency and the inability of the politicians to function as an autonomous socio-political group. In the second half of the 1990s not only did the military succeed in maintaining their political influence but even gained economic and political power. In such a milieu, where there was a danger of losing territory, there was no urge to demand transparency of the defence budget. Would there be any demand when the military's role changed at the end of the decade, and would it be sustained into the 21 st century?

In the 1990s, despite the concordance between the military and the citizenry regarding the army's involvement in politics, a tension emerged between the military and certain groups which either challenge the secular nature of the state (i.e. the Islamists) or its unitary character (i.e. Kurdish nationalists and separatists). Rather than moving only segments of the society, this disturbed the majority of the 
population. They were aware of the fact that there was instability because of the separatist threat to the nation's security and, also, that during crises - when the government was incapable of acting effectively - the military might be disposed to intervene. Since 1960, the military had staged four coups (1960, 1971, 1980 and a soft-coup in 1997) in order to protect national unity, democracy, and secularism. In each take-over, however, most citizens accepted the military's political involvement because of deep popular confidence in the army and its role as an organic part of national society.

Although Turkey's civilian sector is more prominent than it used to be, the military has constitutional tools at its disposal and a supportive political culture, should it choose to play a behind-the-scenes role in the political process. For example, among the very top echelons there is an institutionalised, consultative relationship between the government and the military. When a civilian government is efficient, capable of maintaining political stability, and does not have a strong disagreement with the armed forces' leadership, the military's influence on decision-making is subdued. The top brass exercise more authority in circumstances of political instability and when there is unease in the civil-military partnership. Such freedom of action for the army worries some liberals who desire the progress of democratisation without military intervention; but, to repeat, most citizens are comfortable with the military's role as guardian of democracy and secularism.

The accommodation among the military, political elites, and the citizenry in Turkey partly explains why enhanced professionalism has better enabled the military to meet shared objectives, rather than creating divergence between military and civilian objectives. Further, the army's technological advancement and strengthdemonstrated successfully against PKK terrorism and in international peacekeeping operations - has increased its prestige in the public's eye at a time when the people have dramatically lost their trust in the political parties and parliament (since the 1990s). The sophistication of the military, thanks to a modern military education system, has also enabled it to grasp the complexities of social issues and the needs of the citizenry, and hence, to increase its standing in the public eye. Acquiring complementary civilian and military expertise has enabled officers to enter many professional fields and assume enhanced roles in non-military domains. Today an officer is not the soldier as "warrior" but very much also the soldier as "diplomat and scholar." This is key for civil-military co-operation in many fields. Working toward shared objectives with the population-at-large may lead to the erosion of civilmilitary boundaries, an assumption of the concordance model. This erosion would appear to have been taking place in Turkey since early $1997 .{ }^{10}$

The military's historic role in building the nation - functioning as an agent of change to realise the goals of Ataturk's reforms-and Turkey's tough neighbourhood 
conditions - generally regarded as harbouring serious external treats-have given the armed forces a respected position in society. Therefore, the government often meets the military's stated requirements for modernisation and technological advancement without asking too much about the implications for defence budgeting. The public supports such allocations because the army, as guardian of democracy, is Turkey's most trusted national institution. Such a perception of the military and its historical role does not generate any popular demand for transparency in resources planning and budgeting. On the contrary, it means the public barely conceive the idea of transparency of the defence budget.

Is this situation subject to challenges? Is there any demand for transparency? The answer to both questions is: "yes." There are challenges that have emerged partly out of the conflict between the military and radical groups that are also suspect in the eyes of most Turks: the radical Islamists, pro-Kurdish groups, some Islamist ultranationalists, and some leftists. These groups are unhappy with the military's influence in political decision-making, and a small number of liberal intellectuals share their discontent. Among the radical factions, the Islamists capitalised on the widespread popular disappointment with the late response of the army to the disaster caused by the 17 August 1999 earthquake. The army, however, was quick to respond to the 12 November 1999 Duzce tremor. This re-established public confidence in the army and effectively silenced the radical critics. ${ }^{11}$

Later, the December 2000 and February 2001 fiscal crises - of which more laterprompted popular attention to the defence budget. The leftists and liberal intellectuals became vocal in questioning the position of the military and the level of defence spending. Nevertheless, these groups have tuned their voice depending on changing circumstances, recognising that generally there is strong confidence in the military. (This is discussed below in the section headed "Debate on Transparency of the Defence Budget.”)

The high public faith in the army is related not only to its heroic image, but also to the fact that it has remained relatively free of the corruption that has become endemic in both the government and the civil service. Moreover, aware of the importance of public trust the army is highly sensitive to social and political developments that have consequences for its image in the public. For example, the military responded rapidly to the February 2001 economic crisis and outmanoeuvred those who were planning to discredit the military by pointing out its huge budget that had been taking 18 percent of the state budget since 1984 (when the PKK launched its guerrilla war). ${ }^{12}$ 


\section{Defence Resources Planning and Budgeting}

The annual defence budget "is about $\$ 9$ billion, about 3.5 of the country's gross domestic product and four times the amount spent on education," wrote Douglas Frantz in New York Times in January 2001. ${ }^{13}$ Analysts say billions more are spent through mechanisms that are not reported in the budget. ${ }^{14}$ In the mid-1990s the defence budget constituted around 4.5-5 percent of Turkey's gross domestic product. ${ }^{15}$ After the Cold War, while many European members of NATO reduced their defence expenses, Turkey's military spending increased. For example, between 1990 and1991 the import of major weapons, measured by the SIPRI methodology, increased by about 14 percent, while the European NATO average growth was 0.4 percent. $^{16}$

The military does exercise almost total control of its financing. In theory, any money spent on defence is subject to strict administrative and parliamentary controls. In practice, the Turkish General Staff (TGS) has complete freedom to decide how the funds are spent. When the government presents its budgetary proposals to parliament, defence spending is traditionally the one item that even the opposition does not dare to challenge.

Defence procurement is handled by the domestic and foreign procurement departments in the Ministry of National Defence (MND) and by the civilian Undersecretariat for Defence Industries (UDI). ${ }^{17}$ Procurement is overseen by the Defence Industry Executive Committee (DIEC). This body is chaired by the prime minister and also includes the defence minister, the UDI Under-secretary and the Chief of the Staff; but in practice the Committee is dominated by the military. ${ }^{18}$ Similarly, the defence minister is theoretically responsible for approving the military's assessment of its procurement needs. In practice, the force commanders submit their requirements to the TGS, which formulates proposals. These are then signed by the defence minister and forwarded to the UDI or the procurement departments in the MND. ${ }^{19}$ The domestic and foreign procurement departments in the MND are headed by serving officers, usually one-star generals, while a civilian heads the UDI. During the late 1990s the military also began to dominate the UDI, successfully lobbying for the appointment of retired senior generals as deputy under-secretaries. ${ }^{20}$

The total control of the military over planning and budgeting is related to their influence on political decision-making and their judicial autonomy. Political influence in turn enhances autonomy vis-à-vis civilian control. ${ }^{21}$ The chief of staff becomes de facto commander-in-chief during wartime. ${ }^{22}$ He does not fall under the aegis of the minister of defence, and he conducts military affairs independently of the cabinet. ${ }^{23}$ His office is responsible for drawing up all principles, programmes, and priorities related to personnel, operations, intelligence, training and education, logistic services; 
preparing the armed forces for war; and co-ordinating the ground, naval, and air force commands, as well as other institutions attached to the General Staff. The office also presents its views on the military aspects of international treaties and agreements. If necessary, it participates in meetings regarding such agreements. ${ }^{24}$ The armed forces also enjoy autonomy in the judicial domain. They have their own laws, courts, and judges to deal with matters concerning military personnel, including cases where civilians are involved. ${ }^{25}$

Considerable economic and financial independence and means, for example militaryowned companies, reinforce political and judicial autonomy. ${ }^{26}$ It is the Chief of Staff, not the Prime Minister, or cabinet, or parliament, who oversees arms production and procurement. It is the General Staff that draws up the annual budget of the armed forces that absorbed nearly one-fifth of the state budget before the February 2001 economic crisis. However, this event-which raised inflation and the rate of unemployment and the number of small business bankruptcies, and made labour and business restless - required the military to revise its budget and to adopt a policy of transparency, as part of general concern about the public finances.

\section{Debate on Transparency of Defence Resources Planning and Budgeting}

Despite calls by some radical groups in the 1990s, debate on transparency of defence resources planning and budgeting was almost absent until the year 2000 when indirect pressure to cut the military budget came from the International Monetary Fund (IMF) because of the fiscal crisis in December 2000. The IMF asked the government to trim the budget for the armed forces as part of a package of reforms, in return for $\$ 7.5$ billion in emergency aid. ${ }^{27}$ This generated a debate on the civilian direction and democratic control of defence planning and budgeting, a development that was not well received by the military. Earlier, as mentioned above, there had been isolated advocacy by some groups, including both the Islamists and liberals critical of the military's independent power and autonomy. ${ }^{28}$ Some urged amending the constitution to curtail the military's influence in the powerful National Security Council (NSC). ${ }^{29}$

While the debate on the military budget and transparency in defence spending began in December 2000, it became more vocal after the February 2001 economic crisis, with larger participation by intellectuals. It has also prompted pro-EU circles in Turkey to discuss the issue of increased civilian control over the military and the defence budget. To introduce civilian control over the military by reconsidering the constitutional provision (Article 118) that establishes the NSC as a 'co-ordinating' body that shapes legislation and its implementation is, of course, one of Brussels' targets. ${ }^{30}$ The subordination of the Turkish General Staff to the Ministry of Defence, rather than to the Prime Minister as under the current constitution, is often cited as one of the main criteria for civilian control. The Turkish forces have traditionally 
resisted such a change arguing that, "given the way in which the political system operates in Turkey, politicians would then attempt to exercise patronage and interfere in the day-to-day running of the armed forces." 31

In responding to the February 2001 economic crisis and the new debate on civilian control over defence resources, Turkey's military decided to cut the defence budget in April 2001. On the eve of the government's submission of a request for billions of dollars in international loans, Turkey's Chief of Staff said the military had decided to halt major procurement programmes and to delay 32 modernisation projects aimed to modernise the military. The cost of these projects amounted to $\$ 19.5$ billion. ${ }^{32}$ The military also announced a plan for adopting a policy of transparency: it aimed to provide the public with detailed information on military spending, while giving due importance to the confidentiality required for security. Interestingly, though, the military did not list the projects that would be delayed. They were believed to include projects to co-produce a main battle tank as well as an attack helicopter. These projects had been severely criticised in the Turkish media from December 2002 onwards. Critics argued that, despite two major earthquakes and a fall of the lira, the defence budget share of gross national product had risen over the previous - from 3 percent to 3.3 percent. $^{33}$

At the same time it is a fact that sometimes the military show more concern for the economic well-being of the country than prominent civilians. For example, in 19911993, despite the economic problems, the Demirel government did not raise any objection to a new national defence policy needing a huge budget. It was General Fusunoglu, then Commander of the Turkish Army, who said: "Turkey needs to maintain a powerful army to be able to meet its national security requirements. The existence of this army should not, however, hinder the economic progress of the country." 34

Along with the fiscal crisis another consideration - a regional developmentunderlay the military's willingness to reduce defence spending in 2001. This was a reduction in defence expenditure by Greece, a country in conflict with Turkey. In early April 2001, the reduction of Turkey's military budget came as the government of Prime Minister Bulent Ecevit learned that the long-time rival had opted to postpone a major fighter procurement. In fact, Athens called on Ankara to cooperate in reducing defence expenditures. Greece decided to postpone by at least three years the $\$ 4.4$ billion purchase of the Eurofighter. The decision was associated with a commitment to invest more resources in social programmes.

Turkish officials now said that Turkey regards its main threats as Iraq and Syria, with whom the country has a dispute over the Euphrates-Tigris basin. ${ }^{35}$ At the same time, they acknowledged that Ankara's defence budget was to be reduced by a third 
principally because of the huge drop in the Turkish lira. Furthermore, when the public discussed this issue the military did not welcome the participation of civilians in the debate on planning defence resources and the budget. "Reducing military purchases is a matter which must be discussed by the military authorities," said Huseyin Dirioz, a Turkish Foreign Ministry spokesman: "Turkey's geopolitical conditions are different from those of Greece."

For their part, Greek officials were not urging cuts identical to those concluded in Athens. "Turkey considers Greece a small regional problem," said Greek Defence Minister Akis Tsohatsopoulos: "With 600,000 soldiers, Turkey needs to arm itself against Iran, Iraq and Syria. In this context, there cannot be an arms balance between Turkey and Greece." 36

The change in the position of Greece further motivated the debate on civilian engagement in defence resources planning and budgeting. It gained additional momentum when Mesut Yilmaz first raised the National Security Concept - at the Motherland convention in early August 2001 - and was rebuffed by the military in an extraordinarily tough-worded statement. Yilmaz charged that the National Security Concept adopted by the NSC in the past had stalled reformation and democratisation in Turkey. He pointed out that the internal threat concepts created by the document prevented meaningful debate on crucial issues like freedom of expression and other restrictions on human rights. ${ }^{37}$ Yilmaz's speech was well received by the groups that took a critical position to the uncontested role of the military in determining defence resources and planning. They did not give much credit to the speaker, but applauded the content of the speech. Many agreed on the issues addressed and discussed the non-military participation in defining national security.

In response to Yilmaz's questioning stance, not only did the military lambaste him; they also said the government had ruined the economy. Yilmaz vowed to raise this issue at the NSC meeting on 21 August 2001, while his coalition partners (and President Ahmet Necdet Sezer) said they wanted the controversy shelved. Both Sezer and Prime Minister Bulent Ecevit said they were against the issue being raised at the NSC. They feared an explosive situation if an argument erupted between Yilmaz and the generals, one that might spark a new economic crisis. In the event the meeting passed without incident.

Soon after Yilmaz raised the issue of the military's absolute control over defining "national security," business and labour, the mainstream media, liberal and left-wing analysts all joined the debate on the extent to which civilians and military should be involved. They shared the opinion that the issue of national security is related to all spheres of life and, therefore, along with the political and military elite, various segments of society should have a voice in its definition. This suggests the emergence 
of pressure for transparency of the military budget and participation of civil society institutions in its formation. The debate went on throughout August and early September 2001, despite the military's publicly announced conviction that it was the military that defined national security. ${ }^{38}$

However, with the 11 September terrorist attacks on the US, the agenda has changed. The new international context created by those events and the US-led action in Afghanistan have required the military to re-define threats to national security. The new situation partly silenced the people's urge for defence transparency defence resources. It certainly encouraged the military to increase their spending and to reject the notion of accounting to the public for the expenses. For example, they smartly restored the 32 procurement projects postponed earlier, ostensibly so as to be able to respond effectively to the new threats. ${ }^{39}$

There was no critical response to this development, despite the deepening of the fiscal crisis. $^{40}$ Nor was their reaction to larger cuts in civil spending as Turkey unveiled an austerity budget in October $2001 .^{41}$ A 'new' threat and the changed international conditions created by it had weakened the interest in demanding transparency in the conduct of defence affairs. In the case of Turkey, it froze the campaign.

In the following year, before the general election of 3 November 2002, academics tried to discuss the defence budget and to revive initiatives for transparency in defence budgeting. In August a collection of articles analysing the political role of the army in Turkish politics - and military expenses - was published in the pro-leftist Birikim journal. It inspired many intellectuals to discuss and question the defence budget, but without a serious impact on societal support for transparency in decisionmaking. Another academic voice came from TESEV (a research institute for economic and social studies) with the publication in November 2002 of a research report on military expenditures in Turkey. Conducted by Professor Gulay Gunluk Senesen, the TESEV research shows that defence spending is rising and creating negative consequences for macroeconomic trends. In the conclusion and policy recommendations section of the report Professor Senesen draws attention to the data deficiencies and calls for greater transparency and coherence of defence information. ${ }^{42}$ She also underlines the need for increased public outlays to improve living standards in the process of integration with the European Union and for reevaluation of the perceived and real external and internal threats to the country and the economic costs incurred in meeting them.

It is noteworthy, though, that the TESEV report was not presented at a press conference, as had been planned, because of "political sensitivities" in the postelection period and on the eve of a likely war in Iraq. With the electoral victory of the 
Akparti, many people worried about the implementation of an Islamist agenda, and remembered the role of the army as the guardian of the secular state. This stifled debate on military spending and the defence budget. The likelihood of a war in Iraq further discouraged discussion.

\section{Conclusion}

The analysis of the Turkish case shows that the perception of the military, the nature of civil-military relations and the political culture defining the position of the military vis-à-vis society and the political elite, plus inter-state conflict are factors that affect the citizens' urge for transparency of defence resources planning and budgeting, as hypothesised at the beginning of the paper. The citizen's perception of the military as a sacred and special institution in Turkish society, the heroic image of the military, the public perception of the military as protector of the motherland against external and internal threats, the peculiar nature of civil-military relations that requires a concordance of society and the political elite with the military, the resultant military influence over civilian political life, the constitutional provisions that sanction that influence, and Turkey's tough neighbourhood conditions - this formidable accumulation of factors in fact serves to deter any sustained demand for transparency of defence planning, programming and budgeting in this country.

There have been initiatives for transparency building in Turkey. In 2001 the military responded positively by apparently adopting a policy of transparency. Before that, however, the security environment precluded change; and since, while the EUintegration lobbyists want to reform the country's civil-military relations all round and others campaign for more democratic and accountable government, the position of strength that the army attained in the later 1970s and 1980s has not been seriously eroded. $^{43}$

However, the debate continues. Influential in future will be pressures for reforms to meet the Copenhagen criteria for EU membership. For the time being, though, the events of 11 September 2001 - and more recently the Iraq crisis, conflict and aftermath - cast their shadow over the scene. The military's uncontested role in defence resources planning and budgeting has been enhanced and pressure for defence budget transparency has receded. No less important, after the 2002 electoral victory of Akparti, the fear of an Islamist agenda and potential destabilisation in the Middle East have led Turkish intellectuals to recoil from a critical stance vis-à-vis the military, although perhaps only temporarily. 


\section{Policy Recommendations}

Transparency building is maturing in Turkey and is important for economic development and democratisation. International stimulus for it should go on. Yet most important for Turkey's future stability is the capacity of civilian governments to maintain harmonious relations with the military. This depends on the extent to which they are able to manage the tension created by policy cleavages and the antagonism between the military and the country's radical groups. With increased democratisation, the prospect of European Union membership and enhanced political stability, the military should exert less influence in the political arena. After all, the higher echelons of the military have never evinced anything other than a strong desire to restore a functioning democracy in Turkey. A conviction on the part of the military that there is a strong civilian commitment to protecting the unitary secular state is important, to allow transformation of the NSC - in all respects - into an advisory organ rather than a 'co-ordinating' body. This is one of the mid-term objectives required to be realised in order to meet the Copenhagen criteria, as stated in the Political Criteria Section of the National Programme. ${ }^{44}$

This would likely lead to a more relaxed civil-military partnership with increased civilian influence (eventually dominance) and that in turn would invigorate initiatives for transparency and accountability in the conduct of defence affairs. One significant step has already been taken: in order to carry out the changes envisaged in the National Programme of October 2001, the number of the civilians in the NSC was increased. $^{45}$

At the same time domestic and international actors should recognise the possibility that efforts to discredit the military would lead to political turmoil rather than paving the way for further democratisation born of political instability. Secondly, if ever there are worries about the extremist tendencies of elected representatives, there will be strong popular pressure to halt movement towards parliamentary control of the armed forces. 


\section{The Turkish Armed Forces}

\section{A. The Internal Organization ${ }^{46}$}

$\mathrm{J}-1 \quad$ - responsible for personnel

$\mathrm{J}-2$ - responsible for the collation and evaluation of internal and foreign intelligence from the Turkish National Intelligence Organization, the police and gendarmerie, and the three services' own intelligence branches

J-3 - responsible for operations, training, planning and exercises

$\mathrm{J}-4 \quad$ - responsible for logistics

J-5 - arguably the most important department and is responsible for strategic policies, threat assessment, targeting, budgets and military agreements

J-6 - responsible for communications and electronics

J-7 - responsible for studies of military history and strategy

\section{B. The Laws}

There are three main laws relating to the status and legal responsibilities of the Turkish Armed Forces are:

- The Turkish Constitution (1982);

- The Turkish Armed Forces Internal Service Law (1961);

- The National Security Council Law (1983).

The Turkish Armed Forces Internal Service Law of January 1961 contains the most detailed statement of the legal role and obligations of the military. It specifically charges the military with responsibility for protecting the nature of the Turkish regime, including the Kemalist principles of territorial integrity, secularism and republicanism. Article 35 states:

"The duty of the Turkish Armed Forces is to protect and preserve the Turkish homeland and the Turkish Republic as defined in the constitution" (the 1961 Constitution). ${ }^{47}$

The National Security Council Law of 1983 defines national security in such broad terms that it could, if necessary, be interpreted as covering almost every policy area. Article 2a states that: 
"National security means the defence and protection of the state against every kind of external and internal threat to the constitutional order, national existence, unity, and to all its interests and contractual rights in the international arena including in the political, social, cultural and economic spheres."

Appendix $B$

\section{The View of the Turkish Ministry of Foreign Affairs on Defence Transparency and Confidence Building}

Turkey attaches particular importance to arms control and disarmament processes. For Turkey, active participation in international efforts in these areas, adherence to the relevant international agreements and observance of their full implementation are important elements of her national security policy. As a result of the momentous changes which took place in the European security architecture over the last decade, the general aspiration for a new security system based on co-operation gave a fresh impetus to arms control and disarmament endeavours, which was welcomed by Turkey.

* The Treaty on Conventional Armed Forces in Europe (CFE) was concluded in 1990 and entered into force in July 1992. The CFE Treaty ensured significant reductions in five categories of conventional arms and equipment, namely battle tanks, armoured combat vehicles, artillery systems, combat aircraft and attack helicopters and imposed certain numerical limitations on states parties. As such, Turkey considers the Treaty as the cornerstone of the European security architecture. Turkey has participated in an active and constructive manner in the negotiations started in Vienna and ended in Istanbul for adapting the CFE Treaty to the new conditions which came about with the end of the bipolar structure of the Cold War era.

The Agreement on Adaptation of the Treaty on Conventional Armed Forces in Europe signed in Istanbul on 19 November 1999 will place legally binding limits on the armed forces of every individual country that is party to it, from the Atlantic to the Urals. It will also enhance peace, security and stability throughout Europe and strengthen the requirement that host nations must consent in advance to the deployment of any foreign forces on their territory.

For Turkey the maintenance of the Flank Regime and its reconciliation with the structure of the new Treaty has been the most vital and determining aspect of the 
adaptation process. The substance of this important element of the Treaty is maintained under the adapted CFE.

While expecting all States Parties to complete their ratification process in an expeditious manner, Turkey attaches utmost importance to the full implementation of the present Treaty.

* Turkey considers the Treaty on Open Skies which was concluded in 1992 as a major confidence-building instrument and an important mechanism for the verification of the arms control agreements. In recognition of its significance and potential contribution to European security, Turkey ratified the Treaty in 1994 and stands ready to contribute to efforts directed to facilitating its timely entry into force.

* Turkey regards confidence and security building measures (CSBM) at bilateral and regional levels as an element complementing other disarmament efforts. In this context the Vienna Document constitutes an important CSBM instrument which contributes effectively to the security and stability in the OSCE area and will continue to be an important part of the collective efforts directed to creating a safer and more transparent environment in Europe in the next century. The implementation of the Vienna Document to date has been successful. An important reason underpinning the successful implementation of the Document is its evolving character in the face of new conditions. Within this spirit, as in the previous revisions of the document in 1992 and 1994, the latest process directed to further developing the document has been successfully concluded and as a result, the Vienna Document 1999 was adopted in Istanbul. Turkey believes that this important CSBM arrangement will, in its updated form, make further contributions to openness and transparency in the OSCE area.

As an indication of the importance she attaches to regional security co-operation, Turkey started as from 1990 to conclude with her neighbours in the Balkans bilateral CSBM arrangements drawing upon the Vienna Document. In this context, in 1991 with Bulgaria the "Sofia Document" and then in 1992 as an elaborated version the "Edirne Document," in 1995 with Albania the "Tirana Document" and the same year with Macedonia the "Skopje Document" were finalised and put into practice. Turkey also proposed to materialise similar arrangements with other regional countries.

* Notwithstanding the fresh hopes for a safer environment brought about by the end of the Cold War, the world has also experienced a proliferation of regional conflicts and armed hostilities and witnessed a trend leading to the spread and destabilising accumulation of sophisticated weapon systems including the weapons of mass destruction (WMD) and their means of delivery. 
In view of her particular geographic location close to the regions which bear high risks of proliferation, Turkey monitors with vigilance the developments in this field and takes part in collective efforts aimed at devising measures to reverse this alarming trend.

In this context, Turkey was among the initial signatories of the Non-Proliferation and Test Ban Treaties. Turkey is also party to both the Chemical Weapons and the Biological Weapons Conventions. In 1996, Turkey became the founding member of the Wassenaar Arrangement regarding export controls of conventional weapons and dual-use equipment and technologies and joined the Missile Technology Control Regime (MTCR) in 1997. Turkey recently became a full member to the Zangger Committee. To complete the picture Turkey expects to join the Nuclear Suppliers Group (NSG) and the Australia Group in the nearest future.

Turkey wishes to see, both in her region and at global level, that all countries adhere to the goals of non-proliferation and work collectively for their accomplishment.

* Turkey is fully conscious of the human sufferings and the casualties caused by the irresponsible and indiscriminate use of anti-personnel mines (APMs). However, the security situation around the country so far precluded Turkey from signing the Ottawa Convention aimed at the total elimination of the APMs. Yet, Turkey keeps an open mind towards an eventual mine ban to be achieved in stages. In this context, a national moratorium on the sale and transfer of APMs was put into force in January 1996 and was extended until 2002. Furthermore, Turkey initiated a number of contacts with some neighbouring countries with a view to seeking the establishment of regimes for keeping the common borders free from APMs and for preventing their use in border areas in the future. To this end an agreement was concluded in March 1999 between Turkey and Bulgaria. The agreement has already been approved by the Turkish Grand National Assembly. Turkey also took part as an observer in the First Meeting of States Parties to the Ottawa Convention on 3-7 May 1999, during which she announced her decision to become party to the Convention at the beginning of the next decade, provided that the recent conditions will not change adversely. ${ }^{49}$

\section{Notes:}

1 An earlier version of this paper was presented at International Seminar "Initiatives for Transparency of Defence Resources Planning and Budgeting for Southeast Europe," organised by Department "National and Regional Security" of the University of National and World Economy, Sofia, Bulgaria, 25-26 October 2001.

2 For more information on the academic and political efforts to discuss the concept of transparency building, see Todor Tagarev, "Overview of Defence Transparency Issues in 
Southeast Europe," in Transparency in Defence Policy, Military Budgeting and Procurement, ed. Todor Tagarev (Sofia: Geneva Centre for the Democratic Control of Armed Forces and George C. Marshall-Bulgaria, 2002), pp. 8-14.

3 Prof. Greenwood describes the sequence of events that have led to establishing the conceptual and legal framework of transparency-building in the SEE. Interest was assessed at a Stability Pact Seminar held in Sofia in June of 2000, and the concept was endorsed by the Pact's Working Table III a few months later (October 2000, also in Sofia). Preparations were then made for a formal inauguration. This duly took place in March 2001, on OSCE premises in Vienna. At this gathering a Multinational Steering Group (MSG) was established to manage the enterprise and an Academic Working Group (AWG) was set up to provide professional guidance. The meeting also accepted Bulgaria's offer to provide a small MSG/AWG Secretariat and to host a so-called Group of Experts (GOE) at the Rakovsky Defence College, the latter to act as the working agency of the Initiative. Most important, the Vienna meeting gave the Sofia-based GOE its first tasks. He also explains why transparency-building is important in South-Eastern Europe and generally by referring to 'the Vienna understanding' - that elucidated the meaning and importance of transparency and the closely-related notion of accountability. See David Greenwood, "Transparency in Defence Budgets and Budgeting," in Transparency in Defence Policy, Military Budgeting and Procurement, ed. Todor Tagarev (Sofia: Geneva Centre for the Democratic Control of Armed Forces and George C. Marshall-Bulgaria, 2002), pp.27-38.

Greenwood, "Transparency in Defence Budgets and Budgeting."

Greenwood, "Transparency in Defence Budgets and Budgeting," p. 30.

Greenwood, "Transparency in Defence Budgets and Budgeting."

Vienna Document 1999 of the Negotiations on Confidence- and Security-Building Measures, FSC.JOUR/275 Istanbul, 16 November 1999, <http://www.osce.org/ docs/english/1990-1999/csbms2/vienn99e.htm> (11 February 2003).

For example, according to the 1982 Constitution, Turkey's Council of Ministers must consider, "with priority, the decisions of the National Security Council concerning necessary measures for the protection and independence of the state, the unity and indivisibility of the country, and the peace and security of society" (1982 Constitution, Article 118). The NSC is a constitutional body that had been created by the 1961 Constitution and its status was enhanced by the 1982 Constitution. Article 118 of the 1982 Constitution establishes the NSC as a body evenly divided between five civilians (the president, prime minister, and ministers of defence, internal affairs, and foreign affairs) and five military officials (the chief of the general staff, the commanders of the army, navy, and air force, and the general commander of the gendarmerie).

See Ayse Gul Altinay, Making Citizens, Making Soldiers: Military Service, Gender and National Identity in Turkey, Ph.D Dissertation (Durham, NC: Department of Cultural Anthropology, in Graduate School of Duke University, 2001).

Military officers, for example, joined civilians in celebrating the 75th anniversary of the republic. Military officers in uniform held hands with civilians and marched in Ankara, Istanbul, and Izmir on October 25, 1998, symbolically manifesting the removal of civilmilitary boundaries.

11 Soon after the collapse in public confidence during the national trauma of the August 1999 earthquake, in September 1999 the armed forces still headed the list of trusted institutions with $65.1 \%$. See Milliyet, November 8, 1999. 
The Turkish General Stuff declared to the public that it planed to revise its budget with an aim of reducing the expenses. The General Secretary of the General Stuff issued a press release explaining that the military expenses were to be reduced and the projects that have "no priority" would be postponed or cancelled. It also underlined that the military expenses that had been 18 percent of the total state budget (almost 3.5 percent of the Gross National Product, according to the military's declaration) since 1984 is to be 10.6 percent of the budget in 2001. The military decided to postpone 32 projects in order to save US \$ 19.5 billion. See Radikal, April 12, 2001.

Douglas Frantz, "Military Bestrides Turkey's Path to the European Union," New York Times (January 14, 2001).

See Eric Rouleau, "Turkey's Dream of Democracy," Foreign Affairs 79, 6 (November/December 2000): 100-113; and Douglas Frantz, "Military Bestrides Turkey's Path to the European Union," New York Times (January 14, 2001).

Turkey's military expenditures constituted approximately 5 percent of its gross domestic product in the mid-1990s according to Gulay Gunluk Senesen. This ratio did not include all of the expenditures incurred due to military and paramilitary operations in the southeastern regions. See Gulay Gunluk Senesen, "Some Economic Aspects of Turkish Armaments Spending," New Perspectives on Turkey 13 (Fall 1995): 75-91, p. 75.

Gulay Gunluk Senesen, "Turkey: The Arms Industry Modernisation Program," in Arms Industry Limited, ed. Herbert Wulf (Oxford, UK: Oxford University Press, 1993), pp. 251-267, p. 251.

The Defence Industries Development and Support Administration (DIDA, or UDI) was formed at the end of 1985 to administer the 10 year, $\$ 10$ billion modernisation program. The status of the DIDA was changed to the Under-secretariat for National Defence Industries (UDI) under the auspices of the Ministry of Defence in 1989. See Senesen, "Turkey: The Arms Industry Modernisation Program.” p. 252, footnote 4.

The military dominance of the DIEC was clearly demonstrated in 1998 when the civilian government abolished a defence fund levy on petroleum products. The DIEC, which is ostensibly headed by the prime minister, protested the decision, arguing that it would restrict funds and could delay several important defence programmes. But the civilian government, also headed by the prime minister, defended it on the grounds that it needed to stabilise petrol pump prices and reduce inflationary pressures.

Interview with military official, October 1999.

One reason appears to have been increasing distrust of civilian governments, particularly after the Welfare Party's 1995-election victory, although the military was also concerned about political considerations affecting the equipment purchases. For example, in 1995 the then prime minister Tansu Ciller agreed to buy 30 Cougar utility helicopters from the Franco-German Eurocopter consortium in an attempt to secure French backing for Turkey's Customs Union agreement with the EU despite protests from the TGS, which believed that the US Sikorsky's Black Hawks were a superior platform.

21 For the autonomy of the military in Turkey, also see Umit Cizre Sakallioglu, "The Anatomy of the Turkish Military's Political Autonomy," Comparative Politics 29, 2 (1997): 151-166. p.154.

Article 117 of the Constitution stipulates that the office of the Commander-in-Chief is inseparable from the Turkish Grand National Assembly and that the President of the Republic holds it. According to the same article of the Constitution, the Council of Ministers is responsible to the Turkish Grand National Assembly for national security 
and for the preparation of the Armed Forces for the defence of the country. The article says, "The Chief of the General Staff is the commander of the Armed Forces, and, in time of war, exercises the duties of the Commander-in-Chief on behalf of the President of the Republic." <www.mfa.gov.tr/b6.htm> (12 February 2003).

The Turkish General Staff is not subordinate to the Ministry of Defence, but to the Prime Ministry as under the current constitution. Article 117 of the 1982 constitution, which closely resembles Articles 40 and 110 of the 1924 and 1961 constitutions respectively, states that the Chief of the General Staff is 'appointed by the President of the Republic on the proposal of the Council of Ministers' and 'responsible to the Prime Minister in the exercise of his duties and powers'.

Turkey: An Official Handbook (Ankara: The General Directorate of Press and Information, 1990), p. 60.

Any public criticism of the military found to be "belittling and defaming" (Turkish Penal Code, Article 159) can result in being sentenced up to six years in prison. Such cases are civil criminal courts. Secondly, under Turkish Penal Code Article 155, a public speech or written text found to be containing an aim of "alienating the people from the military" is a crime and tried in General Staff Criminal Court. Crimes of opinion are often tried in state security courts that were presided over by high-ranking officers until the Ocalan case in 2000.

For example, the main one OYAK is a vast composite "comprising some 30 enterprises in sectors as diverse as automobile manufacturing, cement work, food processing, pesticides, petroleum, tourism, insurance, banking, real estates, supermarkets and high technology." See Eric Rouleau, "Turkey's Dream of Democracy," p. 109.

See Douglas Frantz, "Military Bestrides Turkey's Path to the European Union."

For example, the Islamists and the Welfare Party mentioned this attempt a number of times in 1997.

As a result of the crisis, the Turkish lira has dropped by approximately 40 percent.

Eric Rouleau argued that Brussels target a change in the Constitution and "transformation of the NSC into an informal and extra-constitutional consultative body with a civilian majority." See Eric Rouleau, "Turkey's Dream of Democracy," p. 106.

For the opinion of the military on this, see Gareth Jenkins, Context and Circumstance: The Turkish Military and Politics, Adelphi Paper 337 (Oxford: Oxford University Press, February 2001), Chapter III, footnotes 10 and 11, p. 44.

The Turkish General Stuff declared to the public that it planed to revise its budget with an aim of reducing the expenses. It also planed to adopt a policy of transparency that aims to explain and to share some information with the public while considering the importance of confidentiality. The General Secretary of the General Staff issued a press release explaining that the military expenses were to be reduced and the projects that have "no priority" would be postponed or cancelled, as mentioned above. See Radikal (April 12, 2001).

See article titled "Turkey halts $\$ 19.5$ billion in military procurement due to fiscal crisis," Special to World Tribune.com, Middle East Newsline (April 13, 2001).

Quoted in Gulay Gunluk Senesen, "Some Economic Aspects of Turkish Armaments Spending," p. 78.

The existing water conflict over the Euphrates-Tigris basin is an outcome of an intricate two-level interaction between riparian states that involves their domestic political 
concerns as well as strategic international ones. It does not only affect the relations among Turkey, Syria and Iraq, but other Arab countries are also concerned and they do not hesitate to make critical remarks on Turkey's existing water policy.

"Turkey reduces military budget due to economic woes," Special to World Tribune.com Middle East Newsline (April 9, 2001).

Sources close to Yilmaz said Parliament will debate major amendments in the Constitution as of September 17 at an extraordinary session and thus the MGK should debate the proposed constitutional changes. Yilmaz said he would ask the MGK to debate the issue within the light of the proposed constitutional amendments. It is said that the military is sensitive to the amendments in Article 13 of the Constitution, which deals with the restrictions of basic rights and freedoms, Article 14, which deals with the misuse of basic rights and freedoms, Article 26, which deals with how views should be disclosed and how they should be published or aired, and Article 28, which regulates freedom of the press. These articles are among more than three dozen to be changed by Parliament. The military opposes the reforms claiming these could allow Islamic fundamentalist groups as well as Kurdish separatists to spread their propaganda with greater ease. Proponents of the reforms say these improvements are needed if Turkey is to fulfil the Copenhagen criteria and thus open the way for Turkey's full membership to the European Union. See Turkish Daily News (August 21, 2001).

For example, a retired General Sedat Ilhan, speaking to Gazete Gozlem (18 August 2001), said: "The issue of national security cannot be left to the personal whims of the political leaders, and it cannot be discussed by the public." Similar views were expressed in the past. See Nilufer Narli, "Civil-Military Relations in Turkey," paper presented at the International Conference, Taking Stock on Civil-Military Relations, Co-organised by Centre for European Security Studies, The Netherlands, Centre for Security and Defence, Canada, the Geneva Centre for Democratic Control of Armed Forces, Switzerland (The Hague, The Netherlands, 10-12 May 2001).

See Cumhuriyet (September 26, 2001).

Turkey has been in a deep economic crisis since February 2001, with the lira losing over 60 percent of its dollar value while up to a million Turks lost their jobs. Hopes of recovery dwindled after the September 11 terror attacks in the United States and the start of the U.S.-led military campaign in Afghanistan. The government had hoped to base a recovery on higher export and tourism revenues. But regional tensions will likely hurt tourism, while exports could suffer from a global downturn.

41 The budget announced by Sumer Oral aims to slash spending by around 17 percent to meet International Monetary Fund-backed targets. The spending cuts are aimed at reducing the budget deficit from around 15 percent of gross national product this year to under 10 percent of GNP in 2002. See the article by Ben Holland, "Turkey Unveils Austerity Budget," Associated Press Writer (Istanbul, 18 October 2001).

Gulay Gunluk Senesen, Türkiye'de Savunma Harcamaları ve Ekonomik Etkileri: 19802001 /The Military Expense in Turkey and its Implications for the Economy/ (Istanbul: TESEV Publication, 2002). Also see Senesen's article on defence budget in a pro-leftist journal Birikim: "Türkiye'nin Savunma Bütçesi : Veri ve Gozlemler”/Turkey's Defence Budget: Data and Observation/, Birikim 160-161 (August-September 2002): 102-106.

The Turkish General Staff (TGS) initiated the REMO (REorganisation-MOdernisation) project in order to help the army recover from the impact of the 1975 U.S. arms embargo imposed in the wake of the Cyprus intervention the previous year. The project, coupled 
with the impact of internal security concerns, elevated the professional skills of the military, which in turn enlarged its influence on political matters.

44 For the National Program, see <http://www.abgs.gov.tr/> (12 February 2003).

45 In September-October 2001 the Grand National Assembly worked on constitutional changes envisaged in the National Programme. One of them was the change in Article 188 and accordingly, the deputy prime ministers and the ministry of justice have become members of the NSC in October 2001. Now the numbers of civilian members are nine against five military members. See Radikal (29 October 2001).

Internal organisation given below is borrowed from Gareth Jenkins, Context and Circumstance: The Turkish Military and Politics.

Refer to Justice Ministry web site <http://www.adalet.gov.tr> (12 February 2003).

Article 2a, National Security Council Law No 2945, Justice Ministry web site, $<$ http://www.adalet.gov.tr> (12 February 2003).

49 Refer to <http://www.mfa.gov.tr/grupa/ai/01.htm> (12 February 2003).

NILUFER NARLI graduated from the Department of Education (majoring Philosophy, minoring in Sociology) in 1979. After completing her graduate study in the Department of Humanities, she was granted a Malaysian Government Fellowship to study at the University Sains Malaysia (1983-1987) in the School of Comparative Social Sciences. After obtaining her doctoral degree, she began to teach at Marmara University (Istanbul). Currently Professor Narli is the Chair of the Sociology Department and Head of the Unit of Sociology and Anthropology in the Institute of Middle Eastern and Islamic Studies. She has been teaching courses in the field of Middle East studies, political sociology, and conflict resolution.

E-mail: nnarli@yahoo.com. 